\title{
APAKAH GENDER BERMAKNA PADA MODEL PEMBENTUKAN MINAT BERWIRAUSAHA?
}

\author{
Andhy Setyawan \\ Jurusan Manajemen, Fakultas Bisnis dan Ekonomika Universitas Surabaya
}

Email: andhy@staff.ubaya.ac.id

\begin{abstract}
This research purposes to examine the moderating role of gender on the entrepreneurial intention model. The Theory of the Entrepreneurial Event (TEE) and Theory of Planned Behavior (TPB) are integrated as grand theory to explain the research. The data were obtained by involving 154 active undergraduate students as respondents. The results from Structural Equation Modeling (SEM) analysis approach showed that gender moderate the direct effect of entrepreneurial knowledge on entrepreneurial intention significantly. The positive effect of entrepreneurial subjective norm on entrepreneurial intention is stronger and significant in female respondents than males. Furthermore, the effect of the perceived feasibility on entrepreneurial intention is not moderated by gender.
\end{abstract}

Keywords: Gender, Entrepreneurial Intention, Entrepreneurial knowledge. Multigroup SEM

\section{Pendahuluan}

Penelitian mengenai kewirausahaan dalam beberapa dekade terakhir berkembang dengan pesat dan menjadi topik yang menarik untuk dibahas mendalam. Kajian praktis yang ada menunjukkan bahwa wirausaha menjadi keunggulan bersaing bagi negaranegara berkembang untuk dapat bertahan dan terus maju dalam dinamika persaingan di era globalisasi (Nastiti et al., 2010). Shane dan Venkataraman (2000) menunjukkan bahwa penelitian bidang kewirausahaan sangat relevan dan menjanjikan karena kewirausahaan mampu menciptakan lapangan kerja baru dan mempercepat pembangunan ekonomi nasional.

Indonesia sebagai salah satu negara berkembang juga mendorong warganya, terutama generasi muda untuk berwirausaha dengan mencanangkan Gerakan Nasional Kewirausahaan pada bulan Februari 2011. Perbandingan jumlah lapangan kerja tersedia yang tidak sejalan dengan jumlah lulusan di segala level pendidikan di Indonesia menyebabkan tingginya angka pengangguran (Saiman, 2009: 22), sehingga perlu upaya pemerintah untuk mendorong para generasi muda untuk membuka lapangan kerja sendiri atau berwirausaha.

Merujuk pada data publikasi Badan Pusat Statistik (BPS) pada bulan Mei 2014, tingkat pengangguran terbuka di Indonesia pada Februari 2014 mencapai 5,7\%, mengalami penurunan tipis dibandingkan bulan Agustus 2013 sebesar 6,17\%. Namun fakta lain menunjukkan bahwa komposisi pengangguran terdidik semakin tinggi, terutama untuk pendidikan Sekolah Menengah Atas.

Dalam setiap tahun, dari sekitar 3.355 universitas yang beroperasi di Indonesia menghasilkan lebih dari 339.000 lulusan sarjana untuk memasuki pasaran tenaga kerja (Susetyo \& Lestari, 


\section{Andhy Setyawan}

2014). Persaingan untuk menduduki posisi pekerjaan di dalam organisasi menjadi semakin meningkat secara tajam. Kondisi ini menjadi salah satu pemicu utama bagi para calon Iulusan universitas untuk berorientasi pada pilihan karir menjadi wirausahawan.

Sejumlah perguruan tinggi di Indonesia mencanangkan kewirausahaan sebagai bagian dalam program akademik dengan melibatkan mata kuliah tertentu hingga merancang kurikulum untuk menyelenggarakan program pendidikan kewirausahaan secara penuh. Namun demikian, berdasarkan hasil studi yang ada menunjukkan bahwa pelaksanaan pendidikan kewirausahaan di berbagai perguruan tinggi di Indonesia belum dilaksanakan secara optimal, khususnya dalam menyediakan life skill bagi para lulusannya (Wiratno, 2012).

Penelitian empiris yang ada banyak berfokus pada faktor-faktor yang mempengaruhi minat berwirausaha (misal, lihat pada Nastiti et al., 2010; Suharti \& Sirine, 2011; Astuti \& Martdianty, 2012; Solesvik et al., 2012; Ayob et al., 2013; Yang, 2013). Bahkan adapula penelitian yang sudah secara khusus menguji peran pendidikan atau pengetahuan kewirausahaan pada minat berwirausaha (misal penelitian Wilson et al., 2007; Linan et al., 2011; Hattab, 2014). Namun demikian, penelitian yang menjelaskan minat berwirausaha berdasarkan perbedaan individu, seperti jenis kelamin masih terbatas (misal, Diaz-Garcia \& JimenezMoreno, 2010; Maes et al., 2014; Bae et al., 2014) terutama dalam konteks penelitian di Indonesia. Karena itu, tujuan utama dari penelitian ini adalah untuk menguji peran pengetahuan kewirausahaan pada minat berwirausaha dengan memperhatikan moderasi jenis kelamin antar responden mahasiswa pada jenjang S-1 yang sudah mendapatkan mata kuliah Kewirausahaan di Universitas Surabaya, khususnya Fakultas Bisnis dan Ekonomika.

\section{Landasan Teori dan Pengembangan Hipotesis}

Penelitian ini didasarkan pada model penelitian Linan et al. (2011) dengan mempertimbangkan peran jenis kelamin sebagai perbedaan individu yang memoderasi hubungan beberapa variabel dalam model seperti yang diusulkan oleh Diaz-Garcia dan Jimenez-Moreno (2010) serta Bae et al. (2014). Adanya penelitian empiris sebelumnya yang menunjukkan adanya perbedaan minat berwirausaha anatar laki-laki dan perempuan mendorong pemeriksaan model minat berwirausaha yang dimoderasi oleh jenis kelamin.

Model penelitian yang diusulkan oleh Linan et al. (2011) juga sudah diuji secara empiris baik oleh peneliti yang bersangkutanmaupun oleh peneliti lain, seperti yang dilakukan oleh Hattab (2014). Dalam modelnya, Linan et al. (2011) mengintegrasikan dua teori besar, The Theory of Entrepreneurial Event/TEE (Shapero \& Sokol, 1982) dan The Theory of Planned Behavior/TPB (Ajzen, 1991), yang kemudian ditambahkan dengan unsur pengetahuan kewirausahaan yang diperoleh seseorang melalui pendidikan. Kedua teori tersebut (TEE dan TPB) mempunyai kemiripan dalam menyajikan faktor-faktor yang menjelaskan terbentuknya minat berwirausaha.

Dalam perspektif TPB (Ajzen, 1991), minat berwirausaha melibatkan tiga faktor motivasional yang mempengaruhi, yaitu (1) kontrol keperilakuan dipersepsian, yang didefinisikan sebagai persepsi tentang kemudahan atau kesulitan untuk melakukan perilaku tertentu, (2) sikap kewirausahaan terhadap perilaku kewirausahaan, yaitu berkenaan dengan penilaian positif atau negatif yang dimiliki seseorang atas perilaku tersebut, (3) norma subyektif dipersepsian (norma subyektif kewirausahaan), yang mengukur tekanan sosial dipersepsian untuk menjalankan perilaku kewirausahaan. 
Merujuk pada TEE (Shapero \& Sokol, 1982), minat berwirausaha dijabarkan dari hasrat kewirausahaan dan kelayakan dipersepsian, serta kecenderungan bertindak terhadap peluang yang ada. Hasrat kewirausahaan didefinisikan sebagai ketertarikan untuk memulai suatu bisnis. Hasrat kewirausahaan dapat dipahami sebagai gabungan antara sikap pribadi terhadap perilaku kewirausahaan dan norma subyektif dipersepsian. Kelayakan dipersepsian didefinisikan sebagai tingkatan yang dialami individu untuk merasa mampu melakukan, kecenderungan bertindak sebagai disposisi pribadi untuk bertindak pada keputusan-keputusan yang dibuatnya. Dalam literatur di bidang psikologi, kelayakan dipersepsian dikaitkan dengan self efficacy.

Melalui pengintegrasian kedua teori tersebut, Linan et al. (2011) menyajikan penjelasan bahwa melalui pengkombinasian sikap kewirausahaan dan norma subyektif kewirausahaan dipersepsian akan membentuk hasrat kewirausahaan, sedangkan kelayakan dipersepsian direpresentasikan oleh kelayakan dipersepsian atau self efficacy. Selanjutnya, ketiga elemen pembentuk minat berwirausaha dan minat berwirausaha sendiri akan dipengaruhi oleh pengetahuan kewirausahaan yang dimiliki individu melalui pendidikan yang ditempuh.

Merujuk pada berbagai penelitian yang mengakomodasi peran jenis kelamin pada minat berwirausaha (misal penelitian Wilson et al., 2009; Diaz-Garcia \& Jimenez-Moreno, 2010; Shinnar et al., 2012; Maes et al., 2014; Bae et al., 2014), peneliti tertarik untuk menguji peran jenis kelamin pada model minat berwirausaha yang diusulkan oleh Linan et al. (2011). Dalam penelitiannya, Diaz-Garcia dan Jimenez-Moreno (2010) menguji peran moderasi gender pada pengaruh norma subyektif kewirausahaan, kelayakan dipersepsian pada minat berwirausaha. Peran moderasi jenis kelamin pada pengaruh pengetahuan kewirausahaan pada minat berwirausaha diuji dalam penelitian Bae et al. (2014).

Berdasarkan pemaparan kajian teoritis di atas, peneliti mengusulkan hipotesis penelitian sebagai berikut.

H1: Pengetahuan kewirausahaan berpengaruh positif pada sikap kewirausahaan.

H2: Pengetahuan kewirausahaan berpengaruh positif pada norma subyektif kewirausahaan.

H3: Pengetahuan kewirausahaan berpengaruh positif pada kelayakan dipersepsian.

H4: Sikap kewirausahaan berpengaruh positif pada minat berwirausaha.

H5: Jenis kelamin memoderasi pengaruh pengetahuan kewirausahaan pada minat berwirausaha (perempuan lebih kuat).

H6: Jenis kelamin memoderasi pengaruh norma subyektif kewirausahaan pada minat berwirausaha (perempuan lebih kuat).

H7: Jenis kelamin memoderasi pengaruh kelayakan dipersepsian pada minat berwirausaha (perempuan lebih kuat).

Gambar model penelitian yang digunakan dalam penelitian ini ditampilkan pada Gambar 1. 


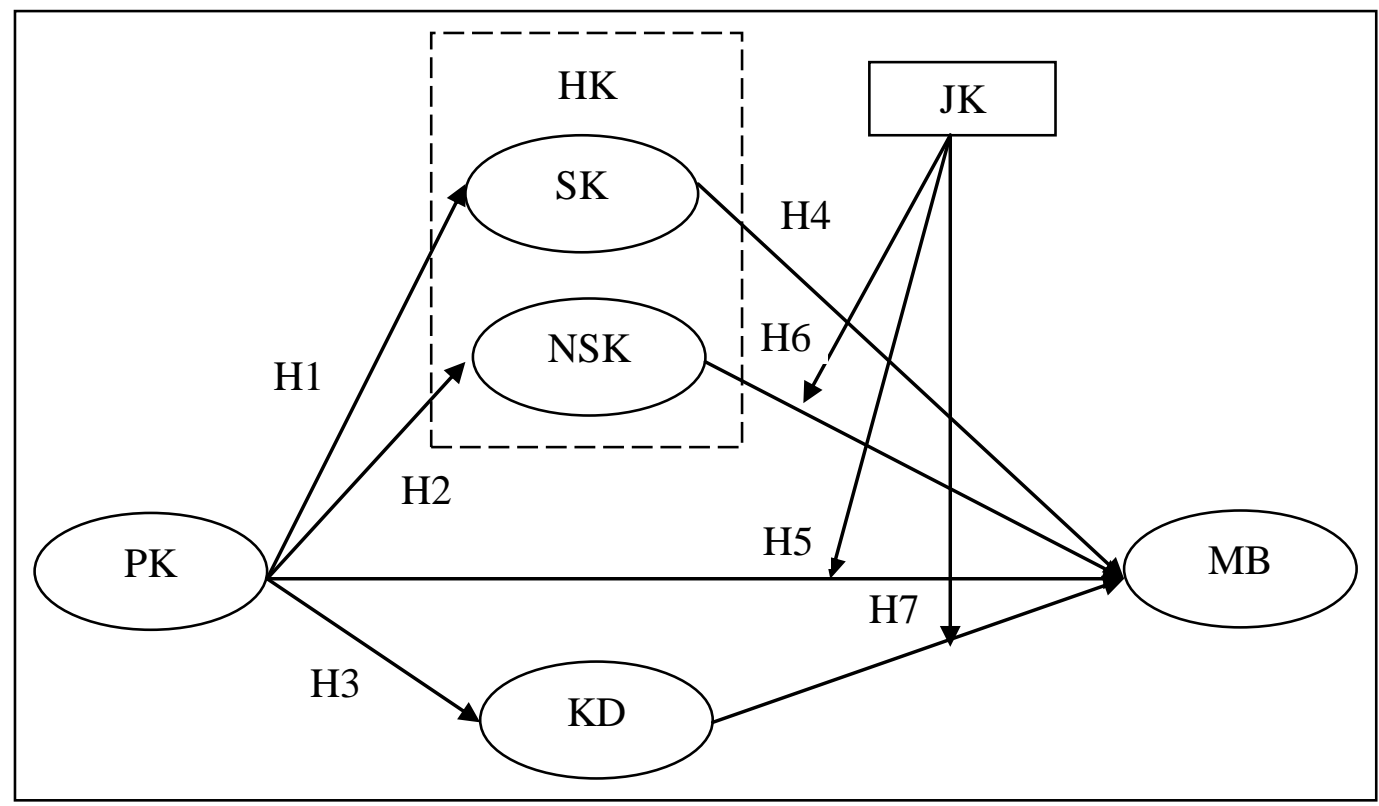

\section{Gambar 1. Model penelitian}

Keterangan:

PK = Pengetahuan kewirausahaan

HK = Hasrat kewirausahaan

SK = Sikap kewirausahaan

NSK = Norma subyektif kewirausahaan

$\mathrm{KD}=$ Kelayakan dipersepsian

$M B=$ Minat berwirausaha

$\mathrm{JK}=$ Jenis kelamin

\section{Metode Penelitian}

Penelitian ini berada dalam area filosofi penelitian positivism (Saunders et al., 2009: 113; Neuman, 2011: 95). Dalam area penelitian positivism, peneliti bekerja dengan mengamati realitas sosial yang ada sampai menemukan suatu bentuk kesimpulan atau hukum tertentu yang dapat digeneralisasi. Strategi penelitian meliputi observasi realitas sosial, membangun hipotesis berdasar teori yang ada, mengumpulkan data yang akurat untuk menguji hipotesis, yang mana hasil pengujian hipotesis akan mengantarkan pada konfirmasi maupun pengembangan teori di masa mendatang. Berdasarkan strategi yang digunakan, penelitian positivism merupakan bentuk pendekatan penelitian yang bersifat deduktif (Saunders et al., 2009: 124).

Penelitian ini bertujuan untuk mendeskripsikan hubungan kausalitas explanatory melalui teknik pengumpulan data secara survei dalam dimensi waktu yang bersifat cross-sectional (Cooper \& Schindler, 201 1: 140; Neuman, 2011: 26). Penelitian bersifat cross-sectional, karena responden penelitian diobservasi dalam suatu saat tertentu dan pengukuran terhadap variabel-variabel dilakukan pada saat penelitian.

Teknik purposive sampling digunakan untuk memperoleh responden sebanyak 154 orang mahasiswa. Responden merupakan mahasiswa Fakultas Bisnis dan Ekonomika Universitas Surabaya yang telah lulus mata kuliah Kewirausahaan. Semua responden mengisi self administered questionnaire dan mengembalikan dengan informasi secara lengkap sesuai dengan instruksi dalam kuesioner tersebut. 
Pengukuran variabel penelitian yang meliputi pengetahuan kewirausahaan, sikap kewirausahaan, norma subyektif kewirausahaan, kelayakan dipersepsian, dan minat kewirausahaan diadaptasi dari penelitian Linan et al. (2011). Pengukuran dari 27 indikator pernyataan menggunakan skala numerik 1-5. Hasil validasi pengukuran dipaparkan pada bagian Hasil dan Pembahasan.

\section{Hasil dan Pembahasan}

\section{Validasi Pengukuran}

Instrumen pengukuran yang digunakan dalam penelitian divalidasi dengan uji validitas dan reliabilitas. Pemeriksaan validitas instrumen pengukuran dilakukan dengan analisis faktor konfirmatori menggunakan AMOS 16. Hasil uji validitas dan reliabilitas ditampilkan sebagai berikut.

\begin{tabular}{|c|c|c|c|c|}
\hline Konstruk & Indikator & $\begin{array}{c}\text { Standardized } \\
\text { Loading }(\lambda)\end{array}$ & $\begin{array}{c}\text { Alpha - } \\
\text { Cronbach (a) }\end{array}$ & Keterangan \\
\hline \multirow{5}{*}{$\begin{array}{l}\text { Pengetahuan } \\
\text { Kewirausahaan } \\
\text { (PK) }\end{array}$} & PK1 & 0,727 & \multirow{5}{*}{$\begin{array}{c}0,825 \\
\text { (Reliabel) }\end{array}$} & Valid \\
\hline & PK2 & 0,590 & & Valid \\
\hline & PK3 & 0,643 & & Valid \\
\hline & PK4 & 0,761 & & Valid \\
\hline & PK5 & 0,772 & & Valid \\
\hline \multirow{4}{*}{$\begin{array}{c}\text { Sikap } \\
\text { Kewirausahaan } \\
\text { (SK) }\end{array}$} & SK1 & 0,649 & \multirow{4}{*}{$\begin{array}{c}0,816 \\
\text { (Reliabel) }\end{array}$} & Valid \\
\hline & SK2 & 0,732 & & Valid \\
\hline & SK3 & 0,753 & & Valid \\
\hline & SK4 & 0,764 & & Valid \\
\hline \multirow{6}{*}{$\begin{array}{c}\text { Norma } \\
\text { Subyektif } \\
\text { Kewirausahaan } \\
\text { (NSK) }\end{array}$} & NSK 1 & 0,597 & \multirow{6}{*}{$\begin{array}{c}0,883 \\
\text { (Reliabel) }\end{array}$} & Valid \\
\hline & NSK2 & 0,651 & & Valid \\
\hline & NSK3 & 0,802 & & Valid \\
\hline & NSK4 & 0,716 & & Valid \\
\hline & NSK5 & 0,821 & & Valid \\
\hline & NSK6 & 0,866 & & Valid \\
\hline \multirow{6}{*}{$\begin{array}{l}\text { Kelayakan } \\
\text { Dipersepsian } \\
\text { (KD) }\end{array}$} & KDl & 0,463 & \multirow{6}{*}{$\begin{array}{c}0,811 \\
\text { (Reliabel) }\end{array}$} & Valid \\
\hline & KD2 & 0,529 & & Valid \\
\hline & KD3 & 0,746 & & Valid \\
\hline & KD4 & 0,787 & & Valid \\
\hline & KD5 & 0,766 & & Valid \\
\hline & KD6 & 0,596 & & Valid \\
\hline \multirow{6}{*}{$\begin{array}{c}\text { Minat } \\
\text { Berwirausaha } \\
\text { (MB) }\end{array}$} & $M B 1$ & 0,701 & \multirow{6}{*}{$\begin{array}{c}0,865 \\
\text { (Reliabel) }\end{array}$} & Valid \\
\hline & MB2 & 0,759 & & Valid \\
\hline & MB3 & 0,793 & & Valid \\
\hline & MB4 & 0,591 & & Valid \\
\hline & MB5 & 0,765 & & Valid \\
\hline & MB6 & 0,722 & & Valid \\
\hline
\end{tabular}

Tabel 1. Hasil uji validitas dan reliabilitas

Merujuk pada Hair et al. (2010: 709), nilai minimal factor loading setiap butir atau indikator yang signifikan secara statistik adalah 0.5 menunjukkan validitas konvergen yang baik. Berdasarkan nilai factor loading pada Tabel 1, terlihat bahwa semua indikator pengukuran 
sudah menunjukkan validitas konvergen yang baik.

Selanjutnya, pengujian reliabilitas konsistensi internal instrumen pengukuran didasarkan pada nilai Cronbach's Alpha (a). Nilai a minimal 0,7 untuk setiap konstruk menunjukkan reliabilitas konsistensi internal yang baik (Hair et al., 2010: 127). Nilai a dari masing-masing konstruk penelitian berada pada kisaran 0,8 , sehingga instrumen pengukuran selain memenuhi uji validitas juga dinyatakan reliabel.

\section{Pengujian Hipotesis}

Setelah melakukan analisis model pengukuran, yang mana instrumen pengukuran dinyatakan valid dan reliabel, langkah selanjutnya adalah menguji hipotesis dengan menjalankan model struktural. Uji model struktural pada penelitian ini dilakukan dengan teknik estimasi maximum likelihood. Kesesuaian model dengan data empirisnya diukur dengan indeks goodness of fit (GOF). Menurut Hair et al. (2010: 672), umumnya tiga sampai dengan empat indeks GOF sudah cukup memberikan bukti mengenai kesesuaian model. Setidaknya peneliti harus melaporkan paling sedikit satu indeks incremental dan satu indeks absolute GOF. Nilai GOF model struktural menunjukkan $\mathrm{Cmin} / \mathrm{df}=1,993 ; \mathrm{GFI}=0,786$; $\mathrm{RMSEA}=0,081 ; \mathrm{CFI}=0,841$; dan $\mid \mathrm{FI}=0,843$; yang relatif baik karena berada pada marginal fit. Tabel 2 menyajikan hasil model struktural.

\begin{tabular}{ccccc}
\hline $\begin{array}{c}\text { Hubungan } \\
\text { Struktural } \\
\text { Antarkonstruk }\end{array}$ & $\begin{array}{c}\text { Nilai Estimasi } \\
\text { Terstandardisasi }\end{array}$ & $\begin{array}{c}\text { Critical } \\
\text { Ratio }\end{array}$ & P-value & Keterangan \\
\hline $\mathrm{PK} \rightarrow \mathrm{SK}$ & 0,101 & 1,022 & 0,307 & H1 tidak terdukung \\
\hline $\mathrm{PK} \rightarrow \mathrm{NSK}$ & 0,339 & 3,397 & ${ }^{* * *}$ & H2 terdukung \\
\hline $\mathrm{PK} \rightarrow \mathrm{KD}$ & 0,350 & 3,092 & 0,002 & $\mathrm{H} 3$ terdukung \\
\hline SK $\rightarrow \mathrm{MB}$ & 0,759 & 6,026 & ${ }^{* * *}$ & $\mathrm{H} 4$ terdukung \\
\hline${ }^{* * *}$ Koefisien signifikan pada $P$-value $<0,001$ & & \\
\hline
\end{tabular}

Tabel 2. Hasil uji hipotesis pada model struktural

\begin{tabular}{|c|c|c|c|c|c|c|}
\hline \multirow{2}{*}{$\begin{array}{l}\text { Hubungan } \\
\text { Struktural } \\
\text { Antarkonstruk }\end{array}$} & \multicolumn{2}{|c|}{$\begin{array}{c}\text { Nilai Estimasi } \\
\text { Terstandardisasi }\end{array}$} & \multirow{2}{*}{$\Delta \chi^{2}$} & \multirow{2}{*}{$\Delta d f$} & \multirow{2}{*}{ P-value } & \multirow{2}{*}{ Keterangan } \\
\hline & $\begin{array}{l}\text { Laki- } \\
\text { laki }\end{array}$ & Perempuan & & & & \\
\hline $\mathrm{PK} \rightarrow \mathrm{MB}$ & $-0,111$ & $0,529 * *$ & 15,346 & 9 & 0,082 & H5 terdukung \\
\hline $\mathrm{NSK} \rightarrow \mathrm{MB}$ & 0,202 & $0,702^{* *}$ & 22,733 & 10 & 0,012 & H6 terdukung \\
\hline$K D \rightarrow M B$ & $0,250^{*}$ & $0,625^{* *}$ & 12,657 & 10 & 0,243 & H7 tidak terdukung \\
\hline \multicolumn{7}{|c|}{${ }^{* *}$ Koefisien signifikan pada $P$-value $<0,001$} \\
\hline *Koefisien signifik & pada $F$ & alve $<0,1$ & & & & \\
\hline
\end{tabular}

Tabel 3. Hasil uji hipotesis pada model struktural dengan moderasi jenis kelamin

Merujuk pada hasil uji hipotesis yang ditampilkan pada Tabel 2 dan Tabel 3, terdapat dua hipotesis yang tidak terdukung $(\mathrm{Hl}$ dan $\mathrm{H} 7)$ dari tujuh hipotesis yang diuji. Data penelitian menunjukkan bahwa pengetahuan kewirausahaan tidak berpengaruh pada sikap kewirausahaan $(\mathrm{H} 1)$, namun berpengaruh positif pada norma subyektif kewirausahaan $(\mathrm{H} 2)$ dan kelayakan dipersepsian (H3). Meskipun pengetahuan kewirausahaan tidak perpengaruh pada sikap, terlihat bahwa sikap kewirausahaan berpengaruh positif pada minat berwirausaha. Secara sederhana, sikap kewirausahaan mendorong timbulnya minat berwirausaha, namun sikap kewirausahaan tidak ditimbulkan oleh pengaruh pengetahuan 
kewirausahaan yang diperoleh melalui jalur pendidikan, tetapi justru oleh faktor yang lain.

Data penelitian juga menunjukkan peran moderasi jenis kelamin secara signifikan pada pengaruh langsung pengetahuan kewirausahaan pada minat berwirausaha $(H 5)$, yang mana pengaruh positif dan bermakna lebih kuat dirasakan oleh para responden berjenis kelamin perempuan. Jenis kelamin memoderasi signifikan pengaruh norma subyektif kewirausahaan pada minat berwirausaha $(\mathrm{H} 6)$, yang mana terlihat dari Tabel 2, pengaruh positif bermakna dan kuat lebih dirasakan oleh para mahasiswi. Selanjutnya, peran mo derasi jenis kelamin tidak signifikan pada pengaruh kelayakan dipersepsian pada minat berwirausaha $(\mathrm{H} 7)$, karena pengaruh kelayakan dipersepsian pada minat berwirausaha antara laki-laki dan perempuan sama-sama postif dan signifikan.

\section{Simpulan}

Berdasarkan pemaparan sebelumnya, hasil penelitian ini menunjukkan bahwa peran moderasi jenis kelamin terlihat nyata dan bermakna pada pengaruh pengetahuan kewirausahaan pada minat berwirausaha. Jenis kelamin juga memoderasi pengaruh norma subyektif kewirausahaan pada minat berwirausaha.Secara umum, responden dengan jenis kelamin perempuan merespon pengaruh tersebut lebih positif dibandingkan dengan laki-laki.

Hasil penelitian juga menunjukkan bahwa pengetahuan kewirausahaan mampu mempengaruhi minat berwirausaha melalui dua cara, yaitu (1) berpengaruh tidak langsung dengan melalui variabel kelayakan dipersepsian tanpa membedakan jenis kelamin, dan melalui variabel norma subyektif kewirausahaan pada responden perempuan; (2) pengetahuan kewirausahaan berpengaruh langsung pada minat berwirausaha mahasiswi.

\section{Daftar Referensi}

Ajzen, I. 1991. The theory of planned behavior. Organizational Behavior and Human Decision Processes, 50: 179-211.

Astuti, R. D., \& Martdianty, F. 2012. Students' entrepreneurial intentions by using theory of planned behavior: The case in Indonesia. The South East Asian Journal of Management, 6: 100-112.

Ayob, N., Yap, C. S., Sapuan, D. A., \& Rashid, M. Z. A. 2013. Social entrepreneurial intention among business undergraduates: An emerging economy perspective. Gadjah Mada International Journal of Business, 15: 249-267.

Bae, T. J., Qian, S., Miao, C., \& Fiet, J. O. 2014. The relationship between entrepreneurship education and entrepreneurial intentions: A meta-analytic review. Entrepreneurship Theory and Practice, 39: 217-254.

Badan Pusat Statistik. 2014. Keadaan ketenagakerjaan Februari 2014. Berita Resmi Statistik, 38: 1-5.

Cooper, D. R., \& Schindler, P. S. 2011. Business research methods (11th ed.). New York, NY: McGraw-Hill.

Diaz-Garcia, M. C., \& Jimenez-Moreno, J. 2010. Entrepreneurial intention: The role of gender. International Entrepreneurship and Management Journal, 6: 261-283.

Hair Jr, J. F., Black, W. C., Babin, B. J., \& Anderson, R. E. 2010. Multivariate data analysis (7th ed.). Englewood Cliffs, NJ: Prentice-Hall. 


\section{Andhy Setyawan}

Hattab, H. W. 2014. Impact of entrepreneurship education on entrepreneurial intentions of university students in Egypt. The Journal of Entrepreneurship, 23: 1-18.

Linan, F., Rodríguez-Cohard, J. C., \& Rueda-Cantuche, J. M. 2011. Factors affecting entrepreneurial intention levels: A role for education. International Entrepreneurship and Management Journal, 7: 195-218.

Maes, J., Leroy, H., \& Sels, L. 2014. Gender differences in entrepreneurial intentions: A TPB multi-group analysis at factor and indicator level. European Management Journal: In press.

Nastiti, T., Indarti, N., \& Rostiani, R. 2010. Minat berwirausaha mahasiswa Indonesia dan Cina. Manajemen \& Bisnis, 9: 188-200.

Neuman, W. L. 2011 . Social research methods: Qualitative and quantitative approaches (7th ed.). Boston, MA: Pearson Education, Inc.

Saiman, L. 2009. Kewirausahaan: Teori, praktik, dan kasus-kasus. Jakarta: Salemba Empat.

Saunders, M., Lewis, P., \& Thornhill, A. 2009. Research methods for business students (5th ed.). Pearson Education Ltd.

Shane, S., \& Venkataraman, S. 2000. The promise of entrepreneurship as a field of research. Academy of Management Review, 25: 217-226.

Shapero, A. \& Sokol, L. 1982. The social dimensions of entrepreneurship. In C. Kent, D. Sexton, \& K. Vesper (Eds.), The encyclopedia of entrepreneurship (pp. 72-90). New York: Prentice Hall.

Shinnar, R. S., Giacomin, O., \& Janssen, F. 2012. Entrepreneurial perception and intentions: The role of gender and culture. Entrepreneurship Theory and Practice, 37: 465-493.

Solesvik, M. Z., Westhead, P., Kolvereid, L., \& Matlay, H. 2012. Student intentions to become self-employed: The Ukrainian context. Journal of Small Business and Enterprise Development, 19: 441-460.

Suharti, L., \& Sirine, H. 2011 . Faktor-faktor yang berpengaruh terhadap niat kewirausahaan. Jurnal Manajemen dan Kewirausahaan, 13: 124-134.

Susetyo, D., \& Lestari, P. S. 2014. Developing entrepreneurial intention model of university students: an empirical study on university students in Semarang Indonesia. International Journal of Engineering and Management Sciences, 5: 184-196.

Wilson, F., Kickul, J., \& Marlino, D. 2007. Gender, entrepreneurial self-efficacy, and entrepreneurial career intentions: Implications for entrepreneurship education. Entrepreneurship Theory and Practice, 32: 387-406.

Wilson, F., Kickul, J., Marlino, D., Barbosa, S. D., \& Griffiths, M. D. 2009. An analysis of the role of gender and self-efficacy in developing female entrepreneurial interest and behavior. Journal of Developmental Entrepreneurship, 14: 105-119.

Wiratno, S. 2012. Pelaksanaan pendidikankewirausahaan di perguruan tinggi. Jakarta: Pusat Penelitian Kebijakan, Badan Penelitian dan Pengembangan, Kementrian Pendidikan dan Kebudayaan.

Yang, J. 2013. The theory of planned behavior and prediction of entrepreneurial intention among Chinese undergraduates. Social Behavior and Personality, 41: 367-376. 